\section{Development of a method to extract and amplify the complete mitogenome of some Sparidae species}

\author{
Celestina Mascolo, ${ }^{1,2}$ Marina Ceruso, ${ }^{1}$ \\ Paolo Sordino, ${ }^{2}$ Giuseppe Palma, ${ }^{3}$ \\ Aniello Anastasio, ${ }^{1}$ Tiziana Pepe ${ }^{1}$
}

${ }^{1}$ Department of Veterinary Medicine and

Animal Production, University of Naples

Federico II, Naples; ${ }^{2}$ Biology and

Evolution of Marine Organisms,

Research Centre Anton Dohrn

Zoological Station, Naples; ${ }^{3}$ Assoittica

Italia, Rome, Italy

\begin{abstract}
Previous studies showed that fish mitochondrial DNA (mtDNA) is set up by a closed circular molecule of 16-17 kilobases (kb), comprising 2 ribosomal RNA genes (rRNA), 22 transfer RNA genes (tRNA), 13 protein-coding genes and 2 non-coding regions. The analysis of single mtDNA genes, such as Cytb, COI, $16 \mathrm{~S}$ and $12 \mathrm{~S}$, or short segment of them, has been widely used against species substitution in both fresh and processed fish products. The analysis of the complete mitochondrial genome of fishery products allows to better study and characterise fish species. The aim of this research was to extract and amplify the complete mtDNA of some fish species of commercial interest belonging to the Sparidae family. The studied species were Dentex dentex, Dentex gibbosus, Dentex nufar, Pagellus acarne and Pagellus erythrinus. The entire mitogenome was obtained by gene amplification using long polymerase chain reactions. The analysis of the complete mitochondrial sequences will allow to gain further insights on these species and to find polymorphic sites that assess the degree of genetic variability of the species belonging to the family Sparidae.
\end{abstract}

\section{Introduction}

The molecular characterisation of the entire mitochondrial genome provides complete genetic information for phylogenetic analysis of organisms. The complete nucleotide sequence of fish mitochondrial genomes was determined from a growing number of species (Miya et al., 2003). Fish mitochondrial DNA (mtDNA) is a circular molecule of 16-17 kilobases $(\mathrm{kb}) \mathrm{kb}$ in length, normally consisting of 2 ribosomal
RNA genes (rRNA), 22 transfer RNA genes (tRNA), 13 protein-coding genes and and 2 non-coding regions (Shi et al., 2012). The study of mtDNA has become a very useful approach in population genetics and evolutionary studies (Manchado et al., 2004) and is used as marker to detect fraudulent substitutions in prepared and transformed fish products (Pepe et al., 2005, 2007); the nucleotide sequences that are fragments belonging to the genes cytochrome $b$ (cyt $b$ ) genes, ribosomal $16 \mathrm{~S}$ and $12 \mathrm{~S}$ subunits, and cytochrome c oxidase subunit 1 (COI) (Espiñeira et al., 2008; Hubalkova et al., 2008; Zhang and Hanner, 2012; Chin et al., 2016). However, the use of short segments of the mtDNA ( 100-700 base pairs) may give ambiguous results, because the fragments are too short to contain sufficient genetic information, and the variations among species are represented by few polymorphisms expressed by point mutations (Bottero et al., 2007). It appears that more mitochondrial genomic information is needed to highlight the presence of more variable regions within the species.

The Sparidae family is one of the most valuable and popular fish resources in the world and comprises about 41 species of different commercial value (D.M. MIPAAF, 31 January 2008; Italian Republic, 2008). Species substitution is very common in prepared and processed fish products, due to the profits resulting from the placing on the market of less expensive species. At the present time, nine Sparidae complete mitochondrial genome sequences are available in GenBank (Acanthopagrus latus, Acanthopagrus schlegelii, Dentex tumifrons, Pagellus bogaraveo, Pagrus auriga, Pagrus major, Parargyrops edita, Rhabdosargus sarba, Sparus aurata). Increase the mitochondrial genomic data on the others Sparidae species appear of great interest.

The extraction and the amplification of the mitochondrial genome is a primary key to correctly continue the study of mitochondrial DNA through the comparison and analysis of properly obtained sequences. The aim of this research was to find a useful method for the extraction and amplification of the complete mtDNA of five fish species of commercial interest belonging to the Sparidae family, with the future aim to analyze and compare them, increasing our knowledge with regard to Sparidae mitogenomics. The mtDNA was isolated using long-polymerase chain reaction (PCR). The long PCR method was selected because represents a major advance for the high-yield purification of mtDNA (Yamauchi et al., 2004) and is one of the most efficient ways to isolate and successfully sequence the
Correspondence: Marina Ceruso, Department of Veterinary Medicine and Animal Production, University of Naples Federico II, via Delpino 1, 80137 Naples, Italy.

Tel.: +39.081.2533905 - Fax +39.081.292981

E-mail: marina.ceruso@gmail.com

Key words: Sparidae; Mitogenome; Method development; Food control.

Conflict of interest: the authors declare no potential conflict of interest.

Ethical approval: all applicable international, national, and/or institutional guidelines for the care and use of animals were followed. This article does not contain any studies with human participants performed by any of the authors.

Funding: this research did not receive any specific grant from funding agencies in the public, commercial, or not-for-profit sectors.

Received for publication: 13 July 2016. Accepted for publication: 13 February 2017.

This work is licensed under a Creative Commons Attribution-NonCommercial 4.0 International License (CC BY-NC 4.0).

CCopyright C. Mascolo et al., 2017

Licensee PAGEPress, Italy

Italian Journal of Food Safety 2017; 6:6154

doi:10.4081/ijfs.2017.6154

entire mitogenome of fishes (Miya and Nishida, 1999).

\section{Materials and Methods}

A total of five different Sparidae species were tested. Here, the species Dentex dentex, Dentex gibbosus, Dentex nufar, Pagellus acarne and Pagellus erythrinus were analyzed. The whole specimens were identified, according to their anatomical and morphological features, as belonging to $D$. dentex, D. gibbosus, D. nufar, P. acarne and $P$. erythrinus species at the Department of Veterinary Medicine and Animal Production, University Federico II, Naples. $D$. dentex specimen was fished in Adriatic sea (near Vieste). D. nufar, P. acarne and $P$. erythrinus specimens were supplied at Salerno fish market. D. gibbosus specimen was collected at Pozzuoli fish market. Fish were frozen on board at $-20^{\circ} \mathrm{C}$ and shipped in insulated boxes to the laboratory. The tissues sampled from each specimen were: tongue muscle, dorsal fin, skeletal muscle, caudal fin and liver. Total DNA was extracted from each sampled tissue, using the following methods: DNeasy tissue kit (Qiagen, 
Hilden, Germany) and NucleoSpin tissue kit (Macherey-Nagel, Düren, Germany), both according to the manufacturer's instructions, CTAB based method (Doyle and Doyle, 1987), salting-out method (Martínez et al., 1998). Extracted DNA was quantified using NanoDrop ND-2000C (Thermo Scientific, Waltham, MA, USA). DNA concentration was expected to be between $\sim 35$ and $200 \mathrm{ng} / \mathrm{mL}$ and the purity of DNA in the range of 1.8-2.0 ratio of absorbance wavelength A260/A280. Electrophoretic analysis was also done using $1 \%$ agarose gel to examine the degree of degradation or the extracted DNA. For the long PCR (Miya et al., 2001), the primers that were used are shown in Table 1.

These primers were chosen after multiple alignment (Figure 1) using BioEdit Sequence Alignment Editor (Hall, 1999) of Sparidae complete mitochondrial genome sequences available in GenBank: Acanthopagrus latus (NC_010977.1, Xia et al., 2008), Acanthopagrus schlegelii (JQ746035.1, Shi et al., 2012), Dentex tumifrons (NC_029479.1, Zeng et al., unpublished), Pagellus bogaraveo (NC_009502.1, Ponce et al., 2008), Pagrus major (NC003196.1, Miya et al., 2001), Pagrus auriga (NC005146.1, Ponce et al., unpublished), Parargyrops edita (EF107158.1, Xia et al., 2007), Rhabdosargus sarba (KM272585.1, Li et al., 2016), Sparus aurata (LK022698.1, Dray et al., 2014). The primers were used to amplify the complete mitochondrial genomes in two long PCRs (two-step strategy) (Figure 2).

Long PCRs (final volume $=50 \mu \mathrm{L}$ ) were performed in a PTC-100 thermal cycler (MJ Research) and standardized as follows: $29.75 \mu \mathrm{L}$ sterile distilled $\mathrm{H}_{2} \mathrm{O}, 10 \mu \mathrm{L}$ Q5 PCR buffer (NEB), $5 \mu \mathrm{L}$ dNTP (2 mM), $0.75 \mu \mathrm{L}$ forward primer $(50 \mathrm{pmol} / \mu \mathrm{L}), 0,5$ $\mu \mathrm{L}$ reverse primer, $1 \mu \mathrm{L}$ of $2000 \mathrm{U} / \mathrm{mL}$ Q5 High-Fidelity Taq polymerase (NEB), and 3 $\mu \mathrm{L}$ (100 ng) of DNA template. The thermal cycle profile is that of shuttle PCR: denaturation at $98^{\circ} \mathrm{C}$ for 10 seconds, with annealing and extension combined at the same temperature $\left(72^{\circ} \mathrm{C}\right)$ for 9 minutes and 20 seconds. Double-stranded PCR products were purified using High Pure PCR Product Purification Kit (Roche, Basilea, Switzerland).

\section{Results}

DNA was correctly extracted from all examined samples. The best quality and quantity of DNA was obtained from the dorsal fin using DNeasy tissue kit (Qiagen).
The long PCR approach allowed to obtain the complete mitochondrial genome of $D$. dentex, D. gibbosus, D. nufar, P. acarne and $P$. erythrinus in two well-resolved amplicons ranging of $\sim 8$ and $\sim 9.5 \mathrm{~kb}$ (amplicon A: L12321-Leu/ S-LA-16SH, and amplicon

B: S-LA-16SH R/ L12321-LeuR, respectively). These two fragments were complementary to each other. High yields of specific long-PCR amplicons were obtained for the tested species D. gibbosus and P. erythrinus, without any further optimization of

Table 1. Sequences of selected long polymerase chain reaction primers.

\begin{tabular}{|c|c|c|c|}
\hline $\mathbf{N}^{\circ}$ & Primer & $5 \Rightarrow 3$ & Temperature $\left({ }^{\circ} \mathrm{C}\right)$ \\
\hline FW 6 & S-LA-16SH R & GATGTTGGATCAGGACATCCYAATGGTGCA & 70.2 \\
\hline FW 5 & L12321-LEU & GGTCTTAGGAACCAAAAACTCTTGGTGCAA & 72.8 \\
\hline REV 2 & S-LA-16SH & TGCACCATTRGGATGTCCTGATCCAACATC & 70.2 \\
\hline REV 8 & L12321-LEU R & TTGCACCAAGAGTTTTTGGTTCCTAAGACC & 72.8 \\
\hline
\end{tabular}

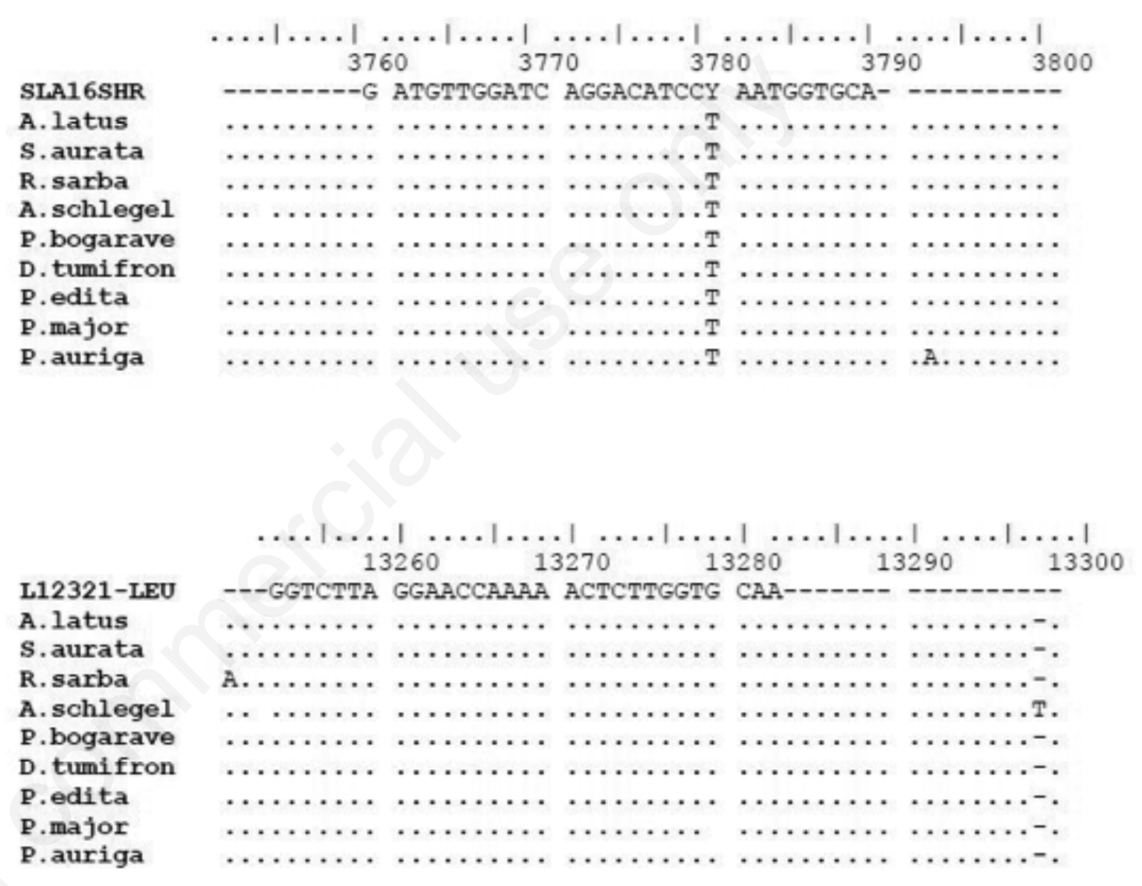

Figure 1. Alignment of forward primer sequences with their respective annealing sites on the mitochondrial genome of 9 Sparidae species. The primer order was 5-3 . Dots indicate identical sites, dashes indicate gaps and divergent sites are indicated by the corresponding nucleotide. Reverse primers (S-LA-16SH, annealing site at 3790 bp; L12321LEU R, annealing site at $13282 \mathrm{bp}$ ) were obtained from the reversed and complement sequences of forward primers.

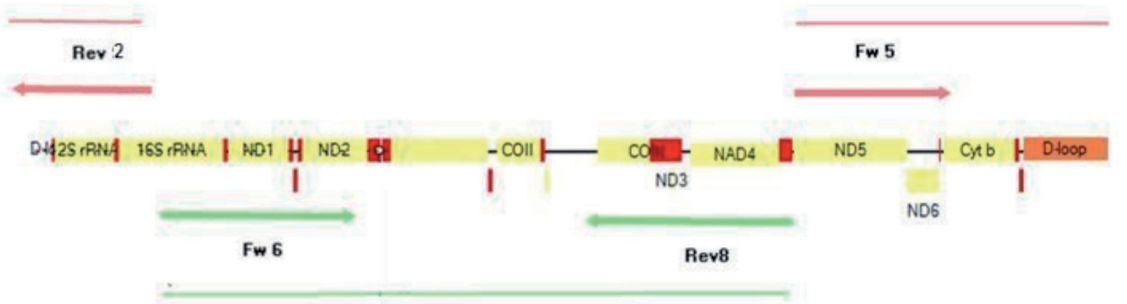

Figure 2. Schematic model of the structural organisation of the Sparidae (e.g. Pagrus major NC003196.1) mitochondrial genome. Primer annealing sites are indicated by green arrows ( $\sim 9.5 \mathrm{~kb}$ amplicon) and pink arrows ( $\sim 8 \mathrm{~kb}$ amplicon). 
the long PCR conditions (Figure 3). Weakness in the reproducibility of amplification was found in the other three species, in particular for the longer $(\sim 9.5 \mathrm{~kb})$ amplicon.

\section{Discussion}

Preliminary results of this study allowed suggesting a useful method for the extraction and amplification of the complete mitogenome of five species belonging to the Sparidae family. The best results were obtained for Dentex gibbosus and Pagellus erythrinus. The amplification was also pos- sible for the other three species Dentex dentex, Dentex nufar and Pagellus acarne, with a still lower degree of reproducibility. For these three species, we are testing different primer set amplifying for smaller fragments designed to facilitate the amplification and the sequencing steps and sets in order to increase the level of reproducibility. The mitogenome amplification is a primary key to correctly continue the study of mitochondrial DNA. The next step of this study will include the sequencing and analysis of the genetic variability of the sequenced mitogenomes. The complete mtDNA is able to provide important information that may highlight the presence of any variable regions within the species, with the aim to design primer sets that are able to amplify species-specific fragments.

\section{Conclusions}

This technique will allow a rapid species identification using a single PCR reaction, providing the basis for the molecular traceability of the fish products, in agreement with the provisions of Regulation (EU) 1379/2013 (European Commission, 2013).

\section{References}

Bottero MT, Dalmasso A, Cappelletti M, Secchi C, Civera T, 2007. Differentiation of five tuna species by a multiplex primer-extension assay. J Biotechnol 129:575-80.

Chin TC, Adibah AB, Danial Hariz ZA, Siti Azizah MN, 2016. Detection of mislabelled seafood products in Malaysia by DNA barcoding: improving transparency in food market. Food Control 64:247-56.

Doyle JJ, Doyle LJ, 1987. A rapid DNA isolation procedure for small quantities of fresh leaf tissue. Phytochem Bull 19:115.

Dray LM, Neuhof M, Diamant A, Huchon D, 2014. The complete mitochondrial genome of the gilthead seabream Sparus aurata L. (Sparidae). Mitochondrial DNA 27:781-2.

Espiñeira M, González-Lavín N, Vieites JM, Santaclara FJ, 2008. Authentication of anglerfish species (Lophius spp) by means of polymerase chain reaction restriction fragment length polymorphism (PCR-RFLP) and forensically informative nucleotide sequencing (FINS) methodologies. J Agr Food Chem 56:10594-9.

European Commission, 2013. Regulation of the European Parliament and of the Councilof 11 December 2013 on the common organisation of the markets in fishery and aquaculture products, amending Council Regulations (EC) No $1184 / 2006$ and (EC) No 1224/2009 and repealing Council Regulation (EC) No 104/2000, 1379/2013/EU. In: Official Journal, L 354/1, 28.12.2013.

Hall TA, 1999. BioEdit: a user-friendly biological sequence alignment editor and analysis program for Windows 95/98/NT. Nucl Acids Symp Ser 41:9598.

Hubalkova Z, Kralik P, Kasalova J,
Figure 3. Long polymerase chain reaction products. Lane $1-\sim 8 \mathrm{~kb}$ amplicon of Dentex gibbosus; lane $2-\sim 8 \mathrm{~kb}$ amplicon of Pagellus erythrinus; lane $3-\sim 9.5 \mathrm{~kb}$ amplicon of Dentex gibbosus; lane 4 - $~ 9.5$ kb amplicon of Pagellus erythrinus; lane 5 - GeneRuler 1 kb DNA Ladder (ThermoFisher Scientific, Waltham, MA, USA); lane 6 - Lambda DNA/HindIII marker (ThermoFisher Scientific). 
Rencova E, 2008. Identification of gadoid species in fish meat by polymerase chain reaction (PCR) on genomic DNA. J Agr Food Chem 56:3454-9.

Italian Republic, 2008. D.M. MIPAAF, 31 January 2008. Available (in Italian) from: https://www.politicheagricole. it/flex/cm/pages/ServeBLOB.php/L/IT/ IDPagina/2563

Li J, Yang H, Xie Z, Yang X, Xiao L, Wang X, Li S, Chen M, Zhao H, Zhang Y, 2016. The complete mitochondrial genome of the Rhabdosargus sarba (Perciformes: Sparidae). Mitochondrial DNA A DNA MappSeq Anal 27:16067.

Manchado M, Catanese G, Infante C, 2004. Complete mitochondrial DNA sequence of the Atlantic bluefin tuna Thunnus thynnus. Fish Sci 70:68-73.

Martínez G, Shaw EM, Carrillo M, Zanuy S, 1998. Protein salting-out method applied to genomic DNA isolation from fish whole blood. Biotechniques 24:238-9.

Miya M, Kawaguchi A, Nishida M, 2001. Mitogenomic exploration of higher teleostean phylogenies: a case study for moderate-scale evolutionary genomics with 38 newly determined complete mitochondrial DNA sequences. Mol
Biol Evol 18:1993-2009.

Miya M, Nishida M, 1999. Organization of the mitochondrial genome of a deep-sea fish, gonostoma gracile (Teleostei: Stomiiformes): first example of transfer RNA gene rearrangements in bony fishes. Mar Biotechnol (NY) 1:416-26.

Miya M, Takeshima H, Endo H, Ishiguro $\mathrm{NB}$, Inoue JG, Mukai T, Satoh TP, Yamaguchi M, Kawaguchi A, Mabuchi K, Shirai SM, Nishida M, 2003. Major patterns of higher teleostean phylogenies: a new perspective based on 100 complete mitochondrial DNA sequences. Mol Phylogenet Evol 26:121-38.

Pepe T, Trotta M, Di Marco I, Anastasio A, Bautista JM, Cortesi ML, 2007. Fish species identification in surimi-based products. J Agr Food Chem 55:3681-5.

Pepe T, Trotta, M, Di Marco I, Cennamo P, Anastasio A, Cortesi ML, 2005. Mitochondrial cytochrome b DNA sequenze variations: An approach to fish species identification in processed fish products. J Food Protect 68:421-5.

Ponce M, Infante C, Jimenez-Cantizano RM, Perez L, Manchado M, 2008. Complete mitochondrial genome of the blackspot seabream, Pagellus bogaraveo (Perciformes: Sparidae), with high levels of length heteroplasmy in the WANCY region. Gene 409:44-52.

Shi X, Su Y, Wang J, Ding S, Mao Y, 2012. Complete mitochondrial genome of black porgy Acanthopagrus schlegelii (Perciformes, Sparidae). Mitochondrial DNA 23:310-2.

Xia J, Xia K, Gong J, Jiang S, 2007. Complete mitochondrial DNA sequence, gene organization and genetic variation of control regions in Parargyrops edita. Fish Sci 73:1042-9.

Xia J, Xia K, Jiang S, 2008. Complete mitochondrial DNA sequence of the yellowfin seabream Acanthopagrus latus and a genomic comparison among closely related sparid species. DNA Seq 19:385-93.

Yamauchi MM, Miya MU, Machida RJ, Nishida, M, 2004. PCR-based approach for sequencing mitochondrial genomes of decapod crustaceans, with a practical example from kuruma prawn (Marsupenaeus japonicus). Mar Biotechnol (NY) 6:419-29.

Zhang J, Hanner R, 2012. Molecular approach to the identification of fish in the South China Sea. PLoS One 7:e30621. 